Authors' copy - for citation, please use the original: Sotarauta, M. \& Linnamaa, R. 1998. Crossing the Many Borders. Finnish Local Development Policies Facing New Challenges. European Planning Studies, 6(2) 229-235.

Markku Sotarauta \& Reija Linnamaa

\title{
Crossing the Many Borders: Finnish Local Development Policies Facing New Challenges
}

\section{Introduction}

As we come to the end of the 20th century we are a confronting complex web of social and environmental issues on one hand and fierce economic competition on the other hand. In many fields there is a quest for new contents for policies. However, it may well be that the solutions to many of the contemporary wicked issues may not be found as directly as earlier believed in a search for correct answers, the creation of new models, design of creative intended policies or appealing visions. Instead of these fairly straightforward measures the solutions may also be found in the communicative (and more or less self-organising) processes of decision-making, policy-making, co-operation, knowledge creation etc., and thus we have proposed, and used ourselves ${ }^{i}$, two hypotheses to work with in order to balance the current focus behind policy-oriented studies:

- $\quad$ the quality of the policy processes is not given enough attention and thus many of the shortcomings faced in local development policy-making are largely due to the fact that policy makers have had too strong a faith in the basic assumptions of classical strategic planning

- $\quad$ strategic policy-making is to be balanced by concentrating more on the quality of policy processes.

(Sotarauta \& Linnamaa 1997a and 1997b)

To better understand many faces of policy processes, we need more process oriented studies, and as Forester (1993) argues, more stories should be told and analysed.

We have dealt with above general level hypotheses in a study focusing on local development policies in three Finnish city-regions and three town-regions, and found them relevant not only from the scientific point of view but also from the policy-makers' point of view. In this briefing we deal with the changing context that has drawn both our and policy-makers' attention towards quality of policy processes. We first describe the evolution of the Finnish local development activities, second we consider the demands contemporary societal changes raise for local economic development policies, and third we evaluate how current developments affect local development policy-making and raise the question about crossing the many borders. 


\section{The Evolution of Local Economic Development Policies in Finland}

In Finland, since the mid 60's the state has tried to avoid regional disparities by active regional policy. (see more about Finnish regional policy in Mønnesland 1994 and Sotarauta 1997.) In addition to the state's active influence on local and regional development municipalities have been able to use their own resources to promote local economic development. Partly this is due to Finland's long tradition of local self-government legislation dating back to the mid 19th century. In the 90's the municipalities' role in promotion of local development has been increasing. Before taking a somewhat more detailed look at current issues, we take a glance at an evolution of local development policies in Finland.

Active promotion of local economic development did not originate at the same time all over the country. It depended on the path according along which each municipality was developing. In many cases structural changes activated municipal efforts to influence their own development. (e.g. Ehrstedt 1994, 45; Nupponen 1986, 135 - 136; Turunen et al. 1990, 22.) Before the World War II Finnish municipalities were not active in the field of promotion of local economic development. Efforts were mainly targeted on increasing professional and vocational training. (Turunen et al. 1990, 33 - 34.) After the war there was an increasing need to deliberately promote local economic development due to the fact that after meeting the war indemnities and finishing the reconstruction period employment opportunities began to fall. In addition, migration flows from the countryside towards cities accelerated, and hence the importance of more active policies at the local level became obvious. (Eskelinen 1974, 291.)

Nevertheless, in the 50's and 60's municipalities concentrated mainly on creating the basic infrastructure needed by local business. However, already in the 60's, some municipalities provided firms with industrial sites and premises to be hired out or bought cheaply. At the turn of 60's and 70's most of the municipalities became more active in their efforts to promote local economic development because of major change of occupational structure and migration flows to urban-regions. Municipalities began to support firms more directly by providing them with loans and guarantees etc. (Koski 1988, 5.) At the same time the number of municipal officers and boards working on promotion of industry, business, trade and occupation increased.

In the 70's promotion of local economic development began to be seen from a more comprehensive point of view. It was seen more as a shared issue for every branch of the municipal organisation, and more emphasis was also laid on efforts that were not directly targeted at the development of the manufacturing sector. In the late 70's unemployment rose, and thus activated development efforts further. In fact, with the growth of big industries declining at that time, many of the traditional industrial municipalities only then began deliberately to promote local development. (Nupponen 1986, 15-16.)

In the 80's, structural changes, the first signs of the emergence of the information society, economy, efficiency and management by results characterised the new phase in local development policies. At that time strategic planning arrived in Finnish public policy-making, and, together with strategies, visions and strategic aims, self-reliance became the key-word in many of the writings and speeches. The focus was widened to cover all the sources of livelihood and not only the manufacturing sector, as was the case earlier in most of the municipalities. (Nupponen 1986; Turunen et al. 1990.) In addition, more stress was laid on intangible measures. Municipalities started to implement development projects focusing on such issues as raising the know-how of local enterprises, encouraging entrepreneurship in general, pro- 
moting business supporting business (accounting, consultation etc.). In the 80's, tangible and intangible development efforts were implemented concurrently.

In the 90's many societal changes have influenced local policies and stressed their significance. Globalization, fierce international competition, Finland joining the EU, the public sector's changing role, the breakthrough of information technologies and severe recession at the beginning of 90's have left their mark on the Finnish practices. Because of the recession the unemployment level rose and, even if it has been decreasing since the mid 90's, it is still high $^{\text {ii }}$.

In addition to the measures used in the 80 's such issues as creation of innovative milieus ${ }^{\mathrm{iii}}$, promotion of internationalization of firms, promotion of R\&D development, promotion of cooperation between companies and educating local people to meet new competence requirements have been stressed. Nowadays Finnish local development policy is based on a networklike mode of action in which several interest groups take part. In addition, it seems to be evident that there is no "third party" to control the network, but rather there is a process controlling itself, in which power does not refer only to traditional direct authoritative power, but to the power that is gained by an ability to argue and communicate, to see the logic other actors depend on, to see and understand their goals and strategies, and to find natural touchingpoints between strategies, i.e. to create local development in co-operation with many organisations in a continuous strategy process. In this work the municipalities' role is to locate possible partners, and to convince them to become in some way involved in local development partnerships. As for example Kautonen and Schienstock (1997) state, the "hidden hand" of the City of Tampere organises and initiates many core actitivities in the field of technology policy. Of course, there are big differences between municipalities in how they see their role in the promotion of local development.

In addition, a fairly significant trend of the 90's is the increasing sub-regional co-operation between municipalities. The reason for its increase is the formal introduction ${ }^{\text {iv }}$ of sub-regions in the new Regional Development Act (1994), and the small size of municipalities. With the new Regional Development Act local government has gained more importance in regional policy ${ }^{\mathrm{v}}$. The new Act splits the responsibility for institutional regional development efforts between state and municipalities. (Horttanainen 1994; Sotarauta 1997.)

Sub-regional co-operation in the promotion of local development started only in the 80 's ${ }^{\mathrm{vi}}$ on a voluntary basis. However, in the 90's it is becoming a significant part of local activities, and several different solutions in organising co-operation have been created. The experiences and success vary greatly between sub-regions. By co-operation municipalities try to compile their resources and co-ordinate their activities better.

As is indicated above, in the 90's interactive and communicative modes of policy-making have been emphasised according to principles of partnership and networks, and thus the local development policy can be defined to be a local and sub-regional level communicative process, in which different aims and strategies of many actors are reconciled, and various interests balanced, and touching-points and concrete means between many objectives are constantly looked for and co-ordinated. In this definition we have used such terms as "to reconcile", "to balance" and "to co-ordinate", because it is doubtful if in a network-like mode of action it is possible to base strategic planning on shared vision and shared will (even if it is constantly stressed in the Finnish policy discourse), if reciprocal interests are not taken into account. In a way local development policy has become, drawing on Hoppe's definition, "a never ending 
series of communications and strategic moves by which various actors in loosely coupled forums of public deliberation construct intersubjunctive meanings. These meanings are continually translated into collective projects, plans, actions, and artefacts, which become the issues in the next cycle of political judgement and meaning constructions and so on". (Hoppe 1993, 77)

The evolution of the Finnish local development policies is summarised in Table 1.

TABLE 1. The evolution of the Finnish local development policies

\begin{tabular}{|c|c|c|}
\hline 1950 & & 2000 \\
\hline straightforward industrial policy & $->$ & comprehensive local development policy \\
\hline few means to promote development & $->$ & versatile selection of means \\
\hline few municipalities active & $->$ & $\begin{array}{l}\text { basically every municipality active in } \\
\text { one way or another }\end{array}$ \\
\hline $\begin{array}{l}\text { one-dimensional organisational structure: } \\
\text { usually board and official within munici- } \\
\text { pal organisation. }\end{array}$ & $->$ & $\begin{array}{l}\text { versatile selection of organisational so- } \\
\text { lutions: municipal companies, inter- } \\
\text { municipal federations, joint companies } \\
\text { with other municipalities, boards, of- } \\
\text { ficer, loose networks etc. }\end{array}$ \\
\hline $\begin{array}{l}\text { "do it alone" relations - activities within } \\
\text { existing public systems, individual deci- } \\
\text { sions in individual municipalities }\end{array}$ & $->$ & $\begin{array}{l}\text { co-arrangements - co-operation, co- } \\
\text { planning, co-steering, co-managing, co- } \\
\text { producing, co-allocation - networks, } \\
\text { clusters, etc. }\end{array}$ \\
\hline
\end{tabular}

\section{An Acute Need to Cross Many Borders}

One of the most challenging features of the changes described above is to forge systems of local governance in support of various organisations engaged in the promotion of local economic development to be able at the same time to compete, to co-operate and create functioning networks with other regions and localities, and to take into account social and environmental effects. Hence, as Cooke $(1995,19)$ points out, in the 1990 's, the key policy recommendation is that the regional and local competitive edge rests on a successful interlining of local and regional networks with global networks. And successful interlining requires a policy process of good quality (see Sotarauta \& Linnamaa 1997a and 1997b). It seems evident that new concepts and the thinking behind them are reforming Finnish policy-making, too, even if many of the practical solutions are still open.

In the 90 's, it seems that the only way to cope with the current pace of changes is to accept and benefit from an increasing interplay between actors. We are moving on towards a system of governance that leads to a multiple overlapping negotiation system between various actors at different levels. However, the question about adapting a new more communicative and interactive way of solving problems and designing policies is not only a technical question. It is very much a matter of mental models, the culture of policy-making and managing. We would argue that there is a lack of relevant scientific results and models of how to cross various institutional, sectoral, organizational and territorial borders that block the new ways of thinking and acting. Thus many of the high flying new models, visions and strategies designed for (and 
with) policy-makers by the academics and consultants easily become redundant. In many of the writings related to the new interactive models the focus has been somewhat overly positive drawing on theoretical considerations and many of the bottlenecks of the practical situations have been relegated in the background. In practice, according to our view, to be able to foster the emergence of learning regions, it is as important to understand the many barriers that are blocking the new models as it is to create new concepts stressing the need to take new directions.

\section{Borders as barriers}

Having been thwarted by the experiences gained in instrumentally oriented planning practices policy-makers are looking for new solutions. The communicative turn in planning (see e.g. Healey 1992, 1995, 1997; Forester 1989, 1993; and Fischer \& Forester 1993), network management (Kickert et al 1997) and modern views on governance (e.g. Kooiman 1993, Pekonen 1995) have lot of potential to tackle new demands, but there is a danger of Utopian idealism included in them too. As Sager $(1994,23)$ states, in planning theory the planners were expected to have a virtually unlimited calculative capacity, and in communicative planning it seems that they are expected to have a virtually unlimited communicative capacity. As we have accepted that such things as constraints of time, resources and knowledge limit instrumental rationalism, we must also see and understand how power and conflicts limit the ideal of communicative action. (see Forester 1993.). We can rest neither on elitist assumptions of restricted policy processes nor on pluralist assumptions of totally open ones, and therefore various borders that inhibit the policy processes from flowing with maximum efficiency should be defined, framed and crossed. Borders can be tangible borders such as institutional, sectoral, organizational and territorial borders, or intangible borders due more to human inabilities.

In the policy process borders as barriers are an ubiquitous problem. Most of the time some of them are clearly visible, but in many cases it is difficult to define them in advance, see their true nature, and thus one of the main aims in communicative planning oriented research could be to identify possible policy borders that function as barriers, and especially identify where and how they emerge, in what ways they are faced and crossed. In Table 2, we have made a tentative classification about borders as barriers and some means to cross them. 
TABLE 2. Borders as barriers and means to cross them

\begin{tabular}{|c|c|c|}
\hline & Borders as barriers & Means to cross the borders \\
\hline $\begin{array}{l}\text { Intangible } \\
\text { borders }\end{array}$ & $\begin{array}{l}\text { Intangible borders are mainly reflected on men- } \\
\text { tal level. They include such issues as: } \\
\text { - incompatibility (i.e. no fit between organi- } \\
\text { zations) } \\
\text { - } \text { isolationism (i.e. some actors may focus } \\
\text { only on their own objectives and results) } \\
\text { - lack of adequate information flow between } \\
\text { partners } \\
\text { - infidelity (i.e. actors may not prefer partners } \\
\text { to other actors) } \\
\text { - prejudiced attitudes towards other actor } \\
\text { incomprehension (caused e.g. by language } \\
\text { used) } \\
\text { lack of discipline (i.e. some actors may not } \\
\text { respect "the written and hidden rules" of the } \\
\text { network) } \\
\text { impecunity (not every actor is able to con- } \\
\text { tribute to the co-operative process) } \\
\text { protection of one's own territory } \\
\text { (Cooke 1996; Sotarauta 1993). }\end{array}$ & $\begin{array}{l}\text { The question about crossing intangible bor- } \\
\text { ders requires more a communicative, inter- } \\
\text { active and processual approach on policy- } \\
\text { making. It is not only a technical question. } \\
\text { It is very much a matter of the culture of } \\
\text { planning. }\end{array}$ \\
\hline $\begin{array}{l}\text { Tangible } \\
\text { borders }\end{array}$ & $\begin{array}{l}\text { - Institutional borders } \\
\text { - Borders between various established } \\
\text { - Societal institutions } \\
\text { Sectoral borders } \\
\text { - Borders between various administrative } \\
\text { sectors in public administration } \\
\text { - Organizational borders } \\
\text { - Borders between decision-making and } \\
\text { action of various organisations, public } \\
\text { and private } \\
\text { Territorial borders } \\
\text { - Borders drawn on maps - between } \\
\text { states, regions, municipalities etc. }\end{array}$ & $\begin{array}{l}\text { In industrial and innovation policies efforts } \\
\text { are made to cross the tangible borders e.g. } \\
\text { by } \\
\text { - development plans (programming), } \\
\text { - implementing various programmes (e.g. } \\
\text { Centre of Excellence programme), } \\
\text { - committees, task forces, working parties } \\
\text { etc. } \\
\text { - development projects }\end{array}$ \\
\hline
\end{tabular}

It must be noted that various borders create barriers to policy processes, but on the other hand without borders processes would diverge too much. In addition it must be noted that borders are always created and designed by human beings, and one of the tasks of borders is to define who is included and who is not. Such definitions do not necessarily become barriers if they remain dynamic reflecting changing situations, and thus they are an essential part of dynamic local governance. If they become static, they may become barriers in local governance.

If borders are to be crossed, it seems that there is less scope for direct policy interventions. Instead, there is an increasing need to involve a pluralistic mixture of public, private, voluntary and community organizations and interest groups, drawn together in issue-based rather than institution-based policy arenas. (Benington, 1994, 33.) In Finland, many of the institutional and administrative borders have been reconsidered, but still there are many intangible borders to cross. They can be found between ministries, municipalities, public and private sectors, etc. In Finland, in the 90's, many efforts have been made to reorganise policymaking. Now we need more emphasis on the intangible side of the coin, on border crossing 
action. What we need is a more communicative planning rooted mode of action behind and within the formal structures.

According to our research it seems that one of the most important bottlenecks in the efforts to cross the many borders is that interdependence between tangible and intangible borders has not been seen. Many time only tangible borders are focused and intangible borders have frustrated the efforts. For example, in the northern Tampere region the major obstacles in the communicative co-operation process between municipalities are prejudiced attitudes towards other municipalities, protection of one's own territory, fear of merging of local governments, and fear of losing autonomy, and in this case, mainly mental level barriers were in practice reflected as both territorial and organisational borders, and thus the quality of the co-operative policy process was rather poor. (Sotarauta 1993.) In the case of border crossing action in Tampere city-region, the worst obstacles to a free flow of policy process were the lack of understanding for the partners' view, protection of one's own territory, prejudiced and oldfashioned attitudes toward other municipalities and fear of working for the others and not benefitting themselves. According to our analyses such issues cannot be reduced simply by formulating better policies or organisational models. (see Sotarauta \& Linnamaa 1997a; 1997b.) Based on these observations the questions about co-operation, networks, clusters, etc. should be seen from a more flexible point of view. There are not only organizational or territorial borders to cross, but a manifold web of borders that are reflected in many ways in practical situations.

\section{Conclusion}

In addition to new intended policies and organizational models, i.e. new answers, that we are sometimes desperately in search of, the core questions may rather be in how human beings are able to agree on a) what is the issue and how to redefine it in order to work together, b) how to approach the redefined issue, from what direction to approach, and with what framework approach is possible, and c) how to be able to create such an approach that empowers relevant actors having some interest in the issue in question to participate in the policy process from their own standpoints. Our view is that policy-making is to be balanced by concentrating more on the quality of communicative policy processes without forgetting the many important content and context related issues.

\section{References}

BENINGTON, J. 1994. Local Democracy and the European Union: The Impact of Europeanisation on Local Governance. Commission for Local Democracy. Research report No 6. London.

COOKE, P. 1995. Planet Europa: Network Approaches to Regional Innovation and Technology Management. Technology Management, vol. 2, pp. 18-30.

COOKE, P. 1996. Economic transformation between globalization and regionalization. Social change - comparative research. Post-graduate course, UTA/Tamcess, 22.-26.4.1996.

EHRSTEDT, O. 1994. Näringspolitik och kommunal verklighet. (Economic development policy and municipal reality) Finlands Kommunförbund. Helsinki.

ESKELINEN, H. 1974. Paikallisen kansanvallan puolesta. Maalaiskuntien liitto/Suomen Kunnallisliitto 1921 - 1971. Suomen Kunnallisliitto. Helsinki. 
FISCHER, F. \& FORESTER, J. (eds.) 1993. The Argumentative Turn in Policy Analysis and Planning. UCL Press Ltd. London.

FORESTER, J. 1989. Planning in the Face of Power. University of California press, Ltd. Berkeley.

FORESTER, J. 1993. Critical Theory, Public policy and Planning Practice. Towards a Critical Pragmatism. State University of New York Press. Albany.

HEALEY, P. 1992. Planning Through Debate: the Communicative Turn in Planning Theory. Town Planning Review, vol. 63, No 2 (April), pp. 143-162.

HEALEY, P. 1995. The Argumentative Turn in Planning Theory and Its Implication for Spatial Strategy Formation. In Pakarinen, T \& Ylinen, H. (toim.) Are Local Strategies Possible? Scrutinising Sustainability. Tampere University of Technology, Department of Architecture, urban planning publications 29. pp. 46-70. Tampere.

HEALEY, P. 1997. Collaborative Planning: Shaping Places in Fragmented Societies. MacMillan. Hong Kong.

HOPPE, R. 1993. Political Judgement and the Policy Cycle: The Case of Ethnicity Policy Arguments in the Netherlands. In Fischer, F. \& Forester, J. (toim.) The Argumentative Turn in Policy Analysis and Planning, s. 77-100. UCL Press Ltd.

HORTTANAINEN, E. 1994. Uudet aluepoliittiset säännökset (New regional policy regulations). Suomen Kuntaliitto, Helsinki.

KAUTONEN, M. \& SCHIENSTOCK, G. 1997. Innovation Organisations and Technology Policy in Tampere Region. Work Research Centre. University of Tampere. Unpublished report of the REGIS project.

KICKERT, W.J.M \& KLIJN, E-H. \& KOPPEMJAN, J. F. M. 1997 Managing Complex Networks: Strategies for the Public Sector. Sage Publications. Broughton Gifford.

KOOIMAN, J. (ed.) 1993. Modern Governance: New Government - Society Interactions. Sage Publications.

KOSKI, A. 1988. Kunnat ja teollisuus. Tutkimus maaseutukuntien teollisuuspolitiikasta ja sen merkityksestä teollisuuden sijaintitekijänä 1960 - 1978 esimerkkialueilla VarsinaisSuomessa, Keski-Suomessa ja Kainuussa. (The local authorities and industry. A study of local authority policies towards industry and their significance for the location of industries in Finland in 1960-1978, with examples from Varsinais-Suomi, Keski-Suomi and Kainuu regions).Turun yliopiston maantieteen laitoksen julkaisuja n:o 117. Turku.

MØNNESLAND, J. 1994. Regional Policy in the Nordic Countries. Nordrefo, 1994:4. Holstebro.

NUPPONEN, P. 1986. Kuntien elinkeinopolitiikka ja yhteiskunnan kehitys. Yhdentoista esimerkkikunnan tarkastelua. (Municipal economic development policy and the development of society. Eleven municipalities as cases in point). Tampereen yliopisto, Aluetieteen laitos sarja B40/1986. Tampere.

PEKONEN, K. 1995. Kohti uutta hallinta-ajattelua julkisessa hallinnossa. (Towards new governance thinking in the public sector). Hallinnon kehittämiskeskus. Painatuskeskus. Helsinki.

SAGER, T. 1994. Communicative Planning Theory. Avebury Ashgate Publishing Ltd. Newcastle upon Tyne.

SOTARAUTA, M. 1993. Kurun, Ruoveden ja Virtain yhteistyö- ja kehittämisstrategiat - kuntien yhteistyö ja muuttuva toimintaympäristö. (Development and Co-operation Strategies of Municipalities of Ruovesi and Kuru and Town of Virrat - Co-operation between 
Municipalities and Changing Environment). Suomen kaupunkiliitto. Acta-sarja 16. Helsinki.

SOTARAUTA, M. 1997. Finnish Regional Policy in Transition: Towards Rigid Planning Machine or Dynamic Governance? European Spatial and Research Policy. Vol 4, No 1. pp. 85-99.

SOTARAUTA, M. \& LINNAMAA, R. 1997a. Kaupunkiseudun elinkeinopolitiikka ja prosessien laatu: Tampere, Turku, Oulu, Seinäjoki, Vammala ja Parkano Benchmarkingvertailussa. [Local development policy in the city regions and the quality of policy process: Benchmarking Tampere, Turku, Oulu, Seinäjoki, Vammala and Parkano] Tampereen yliopisto, Aluetieteen ja Ympäristöpolitiikan laitos, sarja A 19. Tampere.

SOTARAUTA, M. \& LINNAMAA, R. 1997b. The Quality of Local Development Policy Process in Co-operation Between Municipalities: The Cases of Oulu and Seinänaapurit Sub-regions. Paper presented in European Regional Science Association 37th European Congress August 26-29, 1997 Rome, Italy.

TURUNEN, H., MALJOJOKI, P. \& NEUVONEN, L. 1990. Kunnallinen elinkeinopolitiikka työtoimintana. Elinkeinopoliittisen työn kohde- ja teoriahistoriasta Suomen kehitysaluemaaseutukunnissa 1950-luvulta 1980-luvulle. (Local council private enterprise promotion policy as work activity. On the private enterprise promotion work object and theory history in local councils in developing, rural regions in Finland from the 1950's to the late 1980's.) Joensuun yliopiston täydennyskoulutuksen julkaisuja Sarja A, n:o 3. Joensuu.

\footnotetext{
${ }^{\mathrm{i}}$ See Sotarauta \& Linnamaa (1997a and 1997b)

${ }^{\text {ii }}$ In 1994, the unemployment rate was $18.4 \%$, compared to $3.4 \%$ in 1990 . In 1996 the unemployment rate was $16.3 \%$ (Statistics Finland).

iii Perhaps not in the sense indicated in the theories, and the best cases, but in most of the intended strategies the focus is on networking, clusters, innovation, etc.

iv The formal sub-regional division created in the early 90's was based on the one hand on travel to work -areas and on the other hand it was largely based on the existing co-operative situation. Under the new Regional Development Act sub-regions form the smallest regional policy unit.

${ }^{v}$ In addition the new Local Government Act (1995) and some other reforms have widened the self-government of local government

${ }^{\mathrm{vi}}$ However, there are some cases where such co-operation dates back to the 50's.
} 